\title{
PRESERVATION NEWS
}

\section{Prepared by Barbara Brown}

\author{
College Libraries Committee \\ Commission on Preservation and Access
}

- Madison. New lersev. Drew University Library has introduced an in-house repair procedure that involves the use of a mobile book repair truck and specially trained student assistants. The procedure eliminates the need to route to the Conservation Unit items needing minor repair and allows the preservation needs in a given area of the collection to be reviewed at the same time. The mobile book repair truck is taken to areas of the collection which receive heavy use. Books needing minor repair are removed from the shelf, repaired then and there, and returned to the shelf during the same work shift. Procedures include tightening cases, tip-ins, sealing frayed covers, and repairing torn pages. Student employees make tentative conservation decisions in addition to making minor repairs. Items which are found to need more than minor repair are immediately routed to the Conservation Unit. For a general outline of the operation of this system, including an inventory of supplies on the mobile truck and grade levels for conservation student assistants, please contact Jean Schoenthaler, Drew University Library, Madison NJ 07940-4007.

- Training opportunity reminders: The application and registration deadlines for two training opportunities described in last month's column are drawing near. The Association of Physical Plant Administrators (APPA) Seminar, "Preservation of Library and Archival Materials" will be offered February 28 through March 1, 1991. Registration after February 1 is $\$ 375$. Details are available from APPA headquarters: (703) 684-1446; fax (703) 549-2772.

Applications for the Preservation Training Seminar for College Librarians, developed collaboratively by the SOLINET Preservation Program and the Commission's College Libraries Committee, are due March 15, 1991. Application information is available from the SOLINET Preservation Program, 400 Colony Square, Plaza Level, Atlanta, GA 30361-6301; (800) 999-8558.

\section{National Archives preservation conference}

The National Archives will hold its sixth annual preservation conference on March 19, 1991. "Archival Issues in the Preservation of Electronic Records" will address two basic issues: the successful practices currently in use at different archival institutions and the challenges posed by the newer forms of electronic records. Among the questions to be raised at the conference are: How can archivists go beyond physical preservation of the media and concentrate on the preservation of the information's logical structure, interrelationships, and other characteristics which are essential to preserve the "record" character of the information? How can archives guarantee the ability to process today's electronic records on tomorrow's computers? For more information, contact the Conference Coordinator, National Archives, Washington, DC 20408; (202) 501-5540. 